\author{
Jurnal Administrasi Publik \\ Volume XVII (2) 2021: 175-196 \\ P-ISSN: 1858-2168, E-ISSN: 2621-251X \\ doi : $10.52316 /$ jap.v17i2.84
}

\title{
Adaptif, Agile dan Inovatif Kunci SDM Unggul
}

\section{Adaptive, Agile, and Innovative : The Key to Excellent's Human Resources}

\author{
Grace V. Dumalang \\ Pusat Pelatihan dan Pengembangan dan Kajian Manajemen Pemerintahan \\ Jl. Raya Baruga No. 48, Makassar, Sulawesi Selatan \\ wss_saiya@yahoo.co.id
}

\begin{abstract}
Naskah diterima tanggal 25 November 2020. Naskah direvisi tanggal 4 Juni 2021.
Naskah disetujui tanggal 25 Juni 2021.
\end{abstract}

\begin{abstract}
Abstrak
Smart ASN merupakan suatu konsepsi dan nilai baru yang dicanangkan Pemerintah di Tahun 2019 di lingkungan birokrasi Indonesia guna mendorong para aparatur agar mampu beradaptasi menghadapi perubahan eksternal yang bersifat global di lingkungan birokrasi. Penelitian ini bertujuan untuk mendeskripsikan arah kebijakan yang dilakukan berbagai kabupaten/kota di Indonesia dalam upaya membangun SDM aparatur yang berkualitas dalam rangka mewujudkan Smart ASN. Metode penelitian yang penulis gunakan adalah metode PRISMA (Preferred Reporting Items for Systematic Reviews and Meta-analyses) dengan pertimbangan protokol riset metode PRISMA detail dan lengkap yang memungkinkan terhindar dari bias subjektif pada saat melakukan kajian literature. Hasil penelitian menunjukkan bahwa arah kebijakan yang dilakukan pemerintah kab/kota di Indonesia dalam upaya membangun SDM aparatur yang berkualitas dalam rangka mewujudkan Smart ASN pada dasarnya telah mengarah pada Grand Design Pembangunan ASN 2020-2024 yang terdiri dari perencanaan, perekrutan dan seleksi, pengembangan kompetensi, penilaian kinerja dan penghargaan, promosi, rotasi dan karir, serta peningkatan kesejahteraan. Keenam pemerintah daerah dalam penelitian ini telah bergerak ke arah strategi di atas meski masih banyak hal yang perlu disesuaikan dan disempurnakan dalam penerapannya.
\end{abstract}

Kata Kunci: Smart ASN; SDM Aparatur; Agile; Grand Design Pembangunan ASN 20202024

\begin{abstract}
Smart ASN is a new concept and value launched by the Government in 2019 in Indonesian bureaucracy to encourage the apparatus to be able to adapt to global external changes in the bureaucratic environment. This study aims to describe the direction of policies carried out by various districts/cities in Indonesia in an effort to develop quality human resources for the apparatus in order to realize Smart ASN. The research method uses PRISMA (Preferred Reporting Items for Systematic Reviews and Meta-analyses) method with consideration of a detailed and complete PRISMA research protocol that allows avoiding subjective bias when conducting a literature review. The results of the study indicate that
\end{abstract}


the direction of policies carried out by district/city governments in Indonesia in an effort to develop quality human resources in the context of realizing Smart ASN has basically led to Grand Design of ASN Development 2020-2024 which consists of planning, recruitment and selection, competency development, performance appraisals and rewards, promotions, rotations and careers, and welfare enhancement. The six local governments in this study have moved towards the above strategy, although there are still many things that need to be adjusted and perfected in their implementation.

Keywords: Smart ASN; SDM Aparatur; Agile; Grand Design Pembangunan ASN 2020-2024

\section{PENDAHULUAN}

Reformasi birokrasi Indonesia sudah memasuki road map akhir. Di akhir periode road map 2020-2024 diharapkan tercapainya world class bureucracy bisa menjadi jawaban atas sekian permasalahan, pertanyaan, atau keraguan akan kemampuan Indonesia dalam mewujudkan SDM unggul, sekaligus menjadi peletak dasar birokrasi bagi para generasi emas di tahun 2045 mendatang. Generasi emas Indonesia 2045 akan tercapai jika ada pembangunan SDM yang baik dan sistematis, yang ditandai dengan beberapa ciri berikut: (1) memiliki kecerdasan yang komprehensif, yakni produktif dan inovatif, (2) damai dalam interaksi sosialnya dan berkarakter yang kuat, (3) sehat, menyehatkan dalam interaksi alamnya, dan (4) berperadaban unggul (Oktari, 2020). Generasi emas ini diprediksi mencapai 140 juta di tahun 2040 (Kompas, 27 Desember 2017). Pembangunan SDM tersebut merupakan salah satu upaya untuk merespon bonus demografi dan menciptakan peluang dan generasi pekerja keras yang mempunyai kemampuan dan menguasai tehnologi sehingga dapat bersaing secara global. Namun generasi emas tahun 2045 tidak akan terealisasi jika tidak ditindaklanjuti dengan melakukan investasi di bidang pembangunan sumber daya manusia mulai saat ini.

Di sisi lain dunia kini menghadapi era disrupsi 4.0 atau revolusi industri generasi keempat. Revolusi ini mempersyaratkan SDM unggul karena menitikberatkan pada pola digitalisasi dan otomasi di semua aspek kehidupan manusia. Seperti yang disampaikan oleh Presiden Joko Widodo, revolusi industri 4.0 telah mendorong inovasi-inovasi teknologi yang memberikan dampak disrupsi atau perubahan fundamental terhadap kehidupan masyarakat. Perubahan-perubahan tak terduga menjadi fenomena yang akan sering muncul pada era revolusi industri 4.0. Kemajuan ilmu pengetahuan dan teknologi sebagai pemicu revolusi indutri juga diikuti dengan implikasi lain seperti pengangguran, kompetisi manusia vs mesin, dan tuntutan kompetensi yang semakin tinggi (Rezky, 2019). Para aparatur dipaksa untuk beradaptasi terhadap transformasi teknologi agar fungsi pelayanan 
publik bisa lebih efisien, tepat, dan cepat (ㅁaedlulloh, 2020). Di samping itu, RPJM ke-IV (2020-2025) menitikberatkan pada upaya untuk mewujudkan masyarakat Indonesia yang mandiri, maju, adil, dan makmur. Upaya ini tentunya harus didukung oleh SDM yang berkualitas dan berdaya saing.

Hanya saja, data dari Ekonom Institute for Development of Economics and Finance (Indef) dan Badan Pusat Statistik memberikan data yang kurang menggembirakan, tenaga kerja yang ada di Indonesia didominasi oleh mereka yang mengenyam pendidikan dasar dan menengah pertama. Persentasenya, menurut Indef mencapai 58 persen, dan berdasarkan BPS 64,8 persen. Ironisnya lulusan perguruan tinggi yang mengisi dunia kerja tidak sampai 10 persen, berkisar hanya dua hingga delapan persen (Kompas, 2019). Temuan ini akan menjadi kendala terutama jika ada pengabaian, sehingga berpotensi membawa dampak buruk terhadap kondisi sosial masyarakat, seperti kemiskinan, rendahnya kesehatan, pengangguran, dan tingkat kriminalitas yang tinggi.

Di tingkat birokrasi, kemampuan ASN juga dinilai masih belum berkualitas. Data dari Badan Kepegawaian Negara menunjukkan 38 persen dari 4,2 juta ASN saat ini diisi oleh pelaksana administrasi sehingga menjadi beban bagi anggaran negara dan memperlambat layanan publik (dead-weight). Besarnya porsi pelaksana administrasi umum yang tidak memiliki kompetensi spesifik dalam menjalankan roda birokrasi dirasa hanya menjadi parasit birokrasi dan membuat pelayanan publik tidak berjalan dengan baik (LAN, 2020)

Human Capital Index yang dikeluarkan World Bank memang menunjukkan peringkat Indonesia yang masih rendah. Skor Indonesia skornya hanya berada di point 0,54 pada skala 0-1 (data.worldbank.org, 2021). Skor ini tidak jauh berbeda dibanding tahun 2017 lalu dimana perolehan Indonesia di tahun tersebut sebesar 0.53 . Hal ini berarti upaya-upaya yang dilakukan dalam membangun SDM belum berjalan optimal. Hal ini pun sejalan di tingkat birokrasi dimana Indonesia berada di peringkat ke-77 dari 119 negara dalam Global Talent Competitiveness Index dengan nilai 38,04 (Menpan.go.id, 2019 dalam Faedlulloh, 2020). Yang terbaru, E-Government Development Inde (EGDI) di tahun 2020 menunjukkan bahwa Indonesia masih berada di peringkat 88 dari 193 negara. Meski posisi ini naik dibandingkan tahun 2018, namun skor rata-rata EGDI Indonesia masih cukup jauh dari negara-negara ASEAN lainnya (Faedlulloh, 2020). 
Pembangunan Sumber Daya Manusia agar dapat menjadi unggul, produktif, dan mampu bersaing di kancah global menjadi prioritas pemerintah. Penegasan pentingnya pembangunannya SDM juga menandai reorientasi kebijakan pembangunan yang sebelumnya lebih menitik beratkan pada pembangunan fisik. Pemerintah daerah harus mengetahui dan perduli akan kepentingan besar terkait SDM yang harus dipersiapkan, yaitu membangun SDM aparatur yang menguasai teknologi untuk bisa menghadapi era industry 4.0 .

Saat ini proses reformasi birokrasi bidang aparatur negara dalam struktur substansi pembangunan nasional menempati ruang yang sangat strategis dan mendapatkan momentum emas. Hal ini tidak terlepas dari fokus pemerintah pada aspek pembangunan SDM. Idealnya, tata birokrasi Indonesia lima tahun ke depan dilaksanakan berdasarkan pada telaah teoritis dan diskursus yang mengarah pada dua konsep besar model ideal governance, yakni dynamic governance dan diversity governance. Dalam upaya mewujudkan birokrasi berkelas dunia utamanya dengan kondisi tatanan kehidupan baru (new normal), dipandang perlu menguatkan pilar-pilar seperti: profesionalitas SDM ASN, simplifikasi kelembagaan, pelayanan publik yang prima, tatalaksana dan akuntabilitas, serta kebijakan publik berbasis data. Goals dari itu semua diharapkan dapat melahirkan ASN unggul yang mampu memberikan pelayanan publik secara prima, sehingga dapat menjadi katalisator peningkatan kesejahteraan masyarakat secara luas (LAN, 2020).

Smart ASN merupakan suatu konsepsi dan nilai baru yang dicanangkan Pemerintah di Tahun 2019 di lingkungan birokrasi Indonesia. Smart ASN menjadi harapan di tengah kondisi birokrasi Indonesia yang masih berjalan tidak efektif. Pemerintah menaruh perhatian dan harapan besar untuk mendorong para aparatur agar mampu beradaptasi menghadapi perubahan eksternal yang bersifat global di lingkungan birokrasi (Faedlulloh, 2020). Smart ASN ditandai dengan ASN yang memiliki integritas, nasionalisme, profesionalisme, wawasan global, penguasaan IT dan bahasa asing, hospitality, networking, dan entrepreneurship. Melalui Smart ASN ini diharapkan di tahun 2024 mendatang world class bureaucracy dapat tercapai.

\section{Rumusan Masalah}

Berdasarkan permasalahan yang dikemukakan di atas maka yang menjadi rumusan masalah dalam penelitian ini adalah: "Bagaimana arah kebijakan yang dilakukan pemerintah 
kab/kota di Indonesia dalam upaya membangun SDM aparatur yang berkualitas dalam rangka mewujudkan Smart ASN?"

\section{Tujuan dan Manfaat}

Tujuan dari penelitian ini adalah untuk mendeskripsikan arah kebijakan yang dilakukan berbagai kabupaten/kota di Indonesia dalam upaya membangun SDM aparatur yang berkualitas dalam rangka mewujudkan Smart ASN. Dari penelitian diharapkan didapatkan gambaran terkait arah kebijakan pembangunan SDM sehingga daerah lain belajar dan mengupayakan hal yang sama, yang sesuai dengan konteks kedaerahan masing-masing.

\section{TINJAUAN PUSTAKA}

\section{Reformasi Birokrasi}

Reformasi birokrasi adalah usaha sadar dan terencana untuk mengubah: 1) Struktur dan prosedur birokrasi, yakni perubahan yang dilakukan mencakup struktur dan prosedur yang ada pada birokrasi dimaksudkan untuk membuat fungsi dari birokrasi tersebut menjadi lebih efektif dan 2) Sikap dan perilaku birokrat, guna meningkatkan efektivitas organisasi atau terciptanya administrasi yang sehat dan menjamin tercapainya tujuan pembangunan nasional, perubahan yang dimaksud untuk memperbaiki sikap dan perilaku dari birokrasi itu sendiri, yang mana menciptakan kesadaran birokrasi akan tugasnya sebagai pelayan masyarakat. Persyaratan keberhasilan reformasi adalah eksistensi peta jalan (road map), menuju suatu kondisi, status dan tujuan yang ditetapkan sejak awal beserta indikator keberhasilannya (Prasojo, 2009 dalam Faedlulloh, 2020). Saat ini peta jalan tersebut telah ada, tujuannya ingin menjadikan birokrasi di Indonesia menjadi birokrasi berkelas dunia (Zauhar, 2007 dalam Faedlulloh, 2020).

\section{World Class Bureucracy dalam Reformasi Birokrasi}

Istilah world-class (berkelas dunia) menurut Cambridge Dictionary diartikan sebagai seseorang atau sesuatu yang terbaik didalam jenis/kelompoknya di dunia. Pengakuan terbaik ini merujuk pada penetapan standar yang berkualitas dalam hal rancangan, kinerja, kualitas, kepuasan pelanggan, dan nilai ketika dibandingkan dengan seluruh hal yang sama yang berasal dari manapun di dunia (Business Dictionary). Oleh karena itu, pemerintahan berkelas dunia dapat dipahami sebagai pemerintahan yang memiliki kualitas terbaik diantara negaranegara di dunia. Kualitas terbaik dari suatu pemerintahan di suatu negara pada umumnya 
akan nampak dari tercapainya tujuan dari pemerintahan yang dapat dilihat dari beberapa indikator seperti kesejahteraan rakyat dan kepuasan masyarakat atas pelayanan yang diberikan pemerintah. Dalam mencapai tujuan tersebut pemerintahan didukung dan dijalankan oleh pemerintahan. Dengan demikian, kualitas pemerintahan berperan besar dalam menghasilkan pemerintahan yang berkualitas (Adiperdana, 2015)

Perubahan global sangat erat kaitannya dengan perubahan paradigma dalam tata kepemerintahan yang baik. Desentralisasi, otonomi, demokrasi, akuntabilitas publik, transparansi dan ditegakkannya hukum merupakan dorongan yang kuat terhadap lahirnya perubahan dalam manajemen pemerintahan. Dalam konteks ini, maka yang dibutuhkan birokrasi bukan hanya hospitality, tetapi juga berwawasan luas, menguasai teknologi dan berdaya saing. Hal yang juga penting adalah Smart ASN sebagai pelayan dan pendorong pembangunan. Smart ASN merupakan salah satu kunci sukses tata kelola birokrasi dan sistem pemerintahan dengan menggunakan nilai efektivitas, efesiensi, equity, dan ekonomis (Kementerian Kesehatan, 2020 dalam Faedlulloh, 2020).

Smart ASN merupakan aparatur yang memiliki profil nasionalisme, integritas, wawasan global, hospitality, networking, teknologi informasi, bahasa asing dan entrepreneurship yang berperan sebagai digital talent dan digital leader yang mendukung transformasi birokrasi di Indonesia (Mustafa, 2019 dalam Faedlulloh, 2020). Melalui upaya tersebut, tujuan reformasi birokrasi menjadi birokrasi berkelas dunia dapat terwujud. Dalam agenda reformasi birokrasi di Indonesia, Smart ASN ditargetkan bisa tercapai pada tahun 2024. Untuk merealisasikan Smart ASN, Kemenpan RB telah memiliki strategi 6P, yakni 1) perencanaan, 2) perekrutan dan seleksi, 3) pengembangan kapasitas, 4) penilaian kinerja dan penghargaan, 5) promosi, rotasi dan karir, dan 6) peningkatan kesejahteraan. Strategi tersebut saling berkelindan satu sama lain dan memilki urgensi yang sama (Faedlulloh, 2020). Strategi 6P ini didasarkan pada Undang-Undang Nomor 5 Tahun 2014 tentang Aparatur Sipil Negara, Peraturan Pemerintah Nomor 11 Tahun 2017 tentang Manajemen Pegawai Negeri Sipil, dan Peraturan Pemerintah Nomor 49 Tahun 2018 tentang Manajemen Pegawai Pemerintah dengan Perjanjian kerja (PPPK).

Berdasarkan strategi di atas, integritas sebagai nilai ASN terdiri dari tiga aspek, yaitu membangun budaya integritas, disiplin. 


\section{Revolusi Industri 4.0}

Revolusi Industri Revolusi industri 4.0 menjadi fase perubahan besar yang dihadapi dunia saat ini. Revolusi Industri 4.0 merupakan perubahan dalam mekanisme produksi barang dan jasa yang ditandai dengan sejumlah ciri, yaitu dengan penggunaan Internet of Things (IoT) dan Cyber Physical Production System (CPPS) dalam proses produksi baik barang maupun jasa (Schwab, 2016; Vaidya, Ambad, \& Boshle, 2018; Amalia, 2018; Li, Tan, \& Chaudhry, 2019 dalam Faedlulloh, 2020). Dalam perkembangannya, setidaknya terdapat sembilan pilar yang menjadi ciri perkembangan teknologi Revolusi Industri 4.0 yaitu 1) Analisis Big Data, 2) Robot Otonom, 3) Teknologi Simulasi, 4) Integrasi Sistem Horisontal dan Vertikal, 5) Industri Berbasis Internet of Things (IoT), 6) Keamanan Siber, 7) Teknologi Informasi berbasis Cloud, 8) Manufaktur Aditif, 9) Teknologi Augmented Reality (Gerbert et al., 2015; Vaidya et al., 2018 dalam Faedlulloh, 2020).

Dalam gegap gempita kemajuannya, revolusi Industri 4.0 pun masih menyisakan ketidakpastian dalam bagaimana memanfaatkan inovasi teknologi untuk meningkatkan berbagai aspek kehidupan manusia (Morrar, Arman, \& Mousa, 2017 dalam Faedlulloh, 2020). Para pekerja di dunia saat ini berada di tengah pasar kerja yang telah terdisrupsi (Rasiah, Turner, \& Ho, 2019 dalam Faedlulloh, 2020). Pengamatan Frank (2017 dalam Faedlulloh, 2020) menilai revolusi industri 4.0 berdampak sekitar $12 \%$ dari pekerjaan yang sudah ada sekarang akan menghadapi risiko diambil oleh sistem kecerdasan dengan adanya otomatisasi pekerjaan. Sekitar $75 \%$ dari pekerjaan yang sudah ada akan digantikan atau diperkuat oleh bot untuk meningkatkan pekerjaan. Kemudian $13 \%$ pekerjaan baru akan diciptakan seiring diciptakannya kesempatan pendapatan dan/atau kategori pekerjaan yang baru (penciptaan pekerjaan). Di sisi lain, 20\% porsi pekerjaan rutin dan repetitif akan diambil alih oleh mesin. Oleh karena itu, pemerintah perlu melakukan reformasi SDM sedemikian rupa, agar para aparatur tetap relevan melakukan pengabdian sebagai pelayan publik di era revolusi industri 4.0.

\section{Pengembangan Kompetensi Aparatur Sipil Negara (ASN)}

Menurut Tilaar (1998 dalam Rezky, 2019) terdapat tiga tuntutan terhadap SDM dalam era globalisasi, yaitu SDM yang unggul, SDM yang terus belajar, dan SDM yang memiliki nilai-nilai indigeneus. Terpenuhinya ketiga tuntutan tersebut dapat dicapai melalui pengembangan SDM. Dalam upaya pengembangan SDM hendaknya berdasarkan kepada prinsip peningkatan kualitas dan kemampuan kerja. Terdapat beberapa tujuan 
pengembangan SDM, diantaranya adalah: (1) meningkatkan kompetensi secara konseptual dan teknikal, (2) meningkatkan produktivitas kerja, (3) meningkatkan efisiensi dan efektivitas, (4) meningkatkan status dan karier kerja, (5) meningkatkan pelayanan terhadap klient, (6) meningkatkan moral-etis, dan (7) meningkatkan kesejahteraan.

Di masa sekarang terutama era digitalisasi atau revolusi industri 4.0 ASN harus mampu dituntut untuk menggunakan sistem aplikasi teknologi informasi di lingkungan birokasi agar mampu menciptakan tata kelola pemerintahan yang berbasis digital. Dalam rangka mewujudkan ASN yang berkualitas maka perlu diadakan pengembangan kompetensi sebagai upaya dalam meningkatkan pelayanan publik kepada masyarakat terhadap penyelenggaraan pemerintah. Mitrani dalam Spencer dan Spencer (1993) mengatakan bahwa kompetensi sebagai an underlying characteristic's of an individual which is causally relatedto criterionreferenced effective and or superior performance in a job or situasion (karakteristik yang mendasari seseorang dan berkaitan dengan efektifitas kinerja individu dalam pekerjaannnya) (Saputra dan Febri, 2020).

Terdapat lima domain penting dalam pengembangan SDM bidang pendidikan, yaitu profesionalitas, daya kompetitif, kompetensi fungsional, keunggulan partisipatif, dan kerja sama. Asumsi yang mendasari pentingnya kelima domain tersebut adalah sebagai berikut (Rezky, 2019):

1. Profesionalitas. Profesionalitas adalah tingkatan kualitas atau kemampuan yang dimiliki SDM dalam melaksanakan profesinya. Profesinoalisme adalah penyikapan terhadap profesi dan profesinalitas yang dimilikinya. SDM yang profesional adalah mereka yang memiliki keahlian dan keterampilan melalui proses pendidikan dan latihan. Kemampuan yang dimiliki meliputi kemampuan teknik dan kemampuan konseptual dalam memberikan layanan formal sesuai dengan profesi dan keahliannya.

2. Daya Kompetitif. SDM yang memiliki daya kompetitif adalah mereka yang memiliki kemampuan ikut serta dalam persaingan. SDM yang memiliki daya kompetitif adalah mereka yang dapat berpikir kreatif dan produktif. SDM yang berpikir kreatif dapat bersaing dan dapat memunculkan kreasi-kreasi baru. Berfikir kreatif dilandasi dengan kemampuan berpikir eksponensial dan mengeksplorasi berbagai komponen secara tekun dan ulet sehingga menghasilkan suatu inovasi.

3. Kompetensi Fungsional. Kompetensi adalah kemampuan yang dimiliki individu untuk melaksanakan profesinya. Kompetensi fungsional adalah kompetensi pada tataran 
aplikasi tepat waktu dan tepat sasaran. SDM yang memiliki kompetensi fungsional adalah mereka yang memiliki kemampuan dalam mendayagunakan potensi diri yang disumbangkan dalam melaksanakan tugas atau profesinya.

4. Keunggulan Partisipatif. SDM unggul adalah SDM berkualitas yang memiliki kemampuan lebih dibandingkan dengan yang lainnya. Dengan kemampuannya tersebut, SDM yang unggul dapat mencapai prestasi untuk memajuan dirinya, lembaga, bangsa dan negara. Mereka yang memiliki keunggulan dapat survive dalam situasi yang kompetitif karena mereka memiliki banyak pilihan dan kecerdasan untuk mengambil keputusan yang tepat.

5. Kerjasama. Kemampuan kerjasama sangat penting di era globalisasi karena dengan kemampuan tersebut akan menjadi kekuatan bagi suatu organisasi atau institusi. Sesungguhnya, era globalisasi bersifat potensial yang menuntut kemampuan menyeleksi dan mendayagunakannya agar teraktualisasikan hingga bernilai guna. Salah satu upaya mengaktualisasikan potensi tersebut adalah melalui kerjasama.

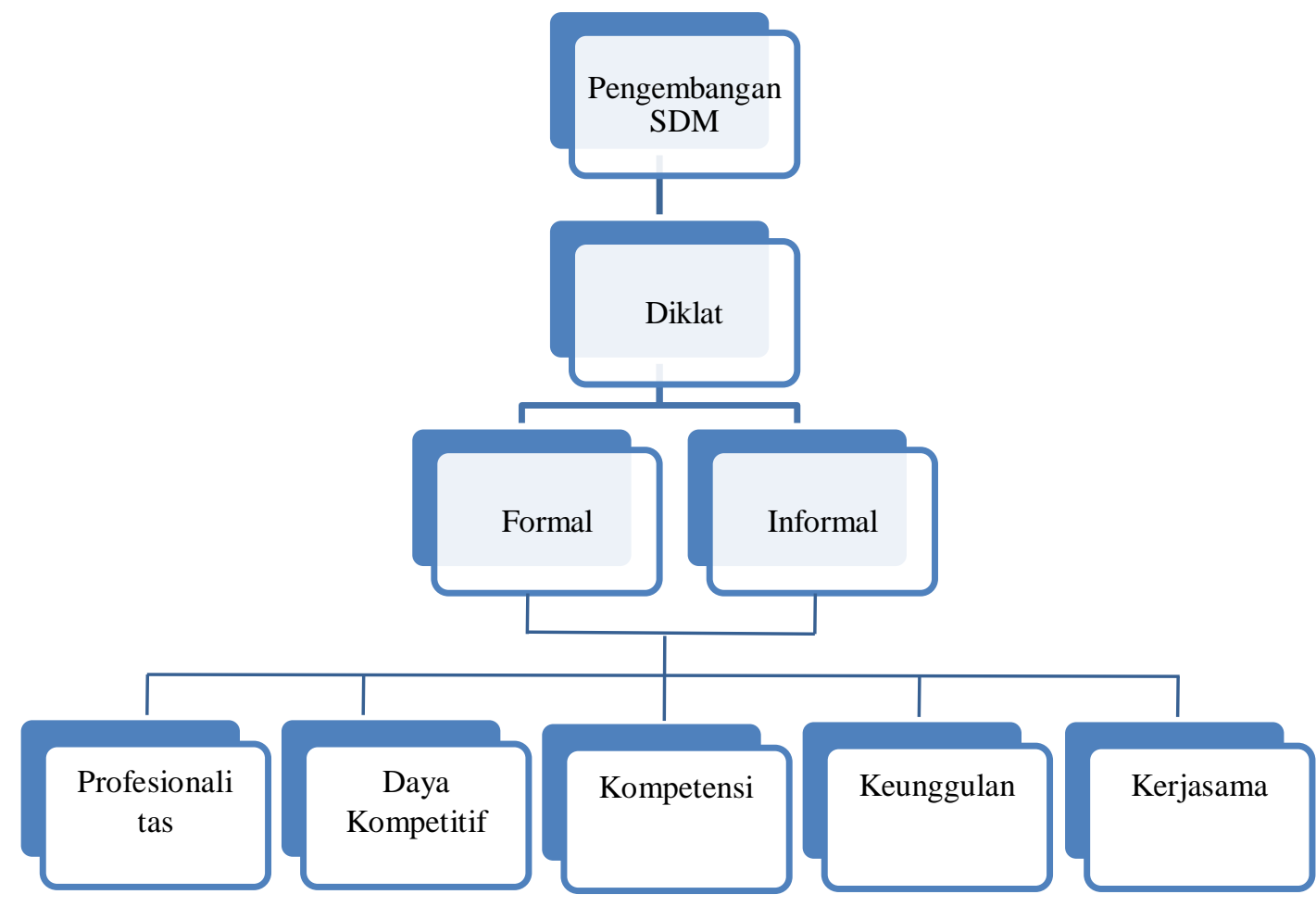

(Sumber : Fukuyama dalam Rezky, 2019) 


\section{METODE PENELITIAN}

Metode penelitian yang penulis gunakan adalah metode PRISMA (Preferred Reporting Items for Systematic Reviews and Meta-analyses). Penulis menggunakan metode ini karena protokol riset metode PRISMA yang detail dan lengkap yang memungkinkan terhindar dari bias subjektif untuk melakukan kajian literatur tanpa melakukan kajian lapangan langsung. Ada lima tahapan penting dalam pelaksanaan PRISMA, yakni 1) Mendefinisikan kriteria kelayakan, 2) mendefenisikan sumber informasi, 3) pemilihan literatur, 4) pengumpulan data, 5) pemilihan item data (Moher et al., 2015:5 dalam Faedlulloh, 2020). Dalam mendefenisikan kriteria kelayakan, artikel yang dijadikan rujukan adalah hasil riset dan kajian yang ditulis baik dalam bahasa Inggris maupun bahasa Indonesia. Artikel-artikel tersebut memiliki substansi dalam pembahasan tentang reformasi birokrasi, revolusi industri 4.0, Smart ASN, dan world class bureucracy yang relevan dengan penelitian ini. Selanjutnya, dalam pendefenisian informasi, proses pencarian literatur dilakukan pada berbagai database online melalui Google Scholar, Website Google, dan Books Google. Selain itu penulis juga mencari literatur yang terkait dokumen road map Reformasi Birokrasi Pemerintah Daerah pada periode 2020-2024. Kemudian, dalam tahap pemilihan literatur, penulis menentukan berdasarkan perpaduan kata kunci reformasi birokrasi, Smart ASN, industrial revolution 4.0, dan world class bureucracy. Dalam tahap pengumpulan data, penulis melakukan pengumpulan secara manual melalui ekstraksi berdasarkan tipe artikel, nama jurnal atau prosiding, tahun, topik, judul, kata kunci dan metode penelitian. Tahap kelima, pemilihan item data yang didapatkan dari artikel-artikel terpilih. Untuk memperdalam analisis, penulis menggunakan beberapa referensi dari bukubuku (textbooks) dan berita yang terkait dengan isu yang diangkat dalam penelitian ini.

\section{HASIL DAN PEMBAHASAN}

\section{Arah Kebijakan Pemerintah Daerah dalam Membangun SDM Aparatur yang Berkualitas dalam Mewujudkan Smart ASN}

Kemenpan RB telah memiliki strategi 6P Untuk merealisasikan Smart ASN, yakni 1) perencanaan, 2) perekrutan dan seleksi, 3) pengembangan kompetensi, 4) penilaian kinerja dan penghargaan, 5) promosi, rotasi dan karir, dan 6) peningkatan kesejahteraan. Keenam strategi diatas kemudian dilihat penerapannya di tingkat pemerintah daerah guna mengetahui apakah daerah telah menjalankan strategi 6P ini dalam arah kebijakan penciptaan Smart ASN. 


\section{Pemerintah Kabupaten Tapin}

Arah kebijakan yang dilakukan Pemerintah Kabupaten Tapin terkait Smart ASN terdapat pada Peraturan Bupati Tapin Nomor 9 Tahun 2020 tentang Road Map Reformasi Birokrasi Pemerintah Tapin Tahun 2019-2023.

a. Perencanaan. Perencanaan dilakukan dalam bentuk penataan sumber daya aparatur, penyusunan analisis jabatan, analisis beban kerja dan evaluasi jabatan, penyusunan kebutuhan formasi pegawai lima tahun ke depan, penyusunan dokumen redistribusi pegawai

b. Perekrutan dan seleksi. Penerimaan pegawai yang transparan, obyektif, akuntabel dan bebas KKN dilakukan melalui pengumuman penerimaan yang diinformasikan secara luas kepada masyarakat; pendaftaran secara online yang mudah, cepat, dan pasti; persyaratan jelas dan tidak diskriminatif; proses seleksi yang transparan, objektif, adil, akuntabel dan bebas $\mathrm{KKN}$, dan pengumuman hasil seleksi diinformasikan secara terbuka.

c. Pengembangan kompetensi. Pengembangan kompetensi pegawai dilakukan melalui pelatihan dalam bentuk pelatihan penyusunan analisa kebutuhan diklat, penyertaan PNS dalam diklat teknis, dan peningkatan kualitas pendidikan aparatur melalui tugas belajar dan izin belajar. Penerapan sistem promosi jabatan pimpinan tinggi dilakukan secara terbuka. Pemerintah Kabupaten Tapin juga melaksanakan penyusunan standar kompetensi jabatan struktural dan fungsional

d. Penilaian kinerja dan penghargaan. Terkait kinerja, hal-hal yang ditetapkan dalam road map terdiri dari sinkronisasi indikator kinerja utama daerah dengan indikator SKPD, sinkronisasi pohon kinerja pejabat pimpinan tinggi sampai dengan pengawas, penetapan kinerja individu melalui penyusunan perjanjian kinerja hingga level pelaksana, dan penyusunan regulasi pedoman penilaian kinerja individu terkait kinerja organisasi, cascading kinerja hingga level pelaksana, pengumpulan data capaian kinerja triwulan, penyusunan laporan kinerja daerah dan organisasi perangkat daerah secara terbuka, pelaksanaan evaluasi kinerja penyelenggaraan pemerintahan di kabupaten Tapin, integrasi e-sakip, e-planning, dan e-budgeting. Terkait penghargaan, arah kebijakan daerah dilakukan melalui penilaian kinerja berbasis online. Reward dan punishment yang diberikan didasarkan pada kinerja. 
e. Promosi, rotasi, dan karir. Promosi para pejabat pimpinan tinggi dilakukan secara terbuka melalui seleksi terbuka jabatan pimpinan tinggi (asessment centre atau talent pool)

f. Peningkatan kesejahteraan. Peningkatan kesejahteraan berupa pemberian tunjangan yang didasarkan pada capaian kinerja individu

\section{Pemerintah Kabupaten Sanggau}

Arah kebijakan Pemerintah Kabupaten Sanggau terkait Smart ASN terdapat pada Peraturan Bupati Sanggau Nomor 4 Tahun 2020 tentang Road Map Reformasi Birokrasi Pemerintah Sanggau Tahun 2020-2024.

a. Perencanaan. Perencanaan kebutuhan pegawai sesuai kebutuhan organisasi dilakukan dalam bentuk penyempurnaan hasil analisis jabatan dan analisis beban kerja, penghitungan kebutuhan pegawai seluruh perangkat daerah, penyusunan rencana redistribusi pegawai, penyusunan proyeksi kebutuhan pegawai selama lima tahun. Penyusunan evaluasi jabatan untuk menetapkan grade/kelas jabatan, penetapan grade/kelas jabatan

b. Perekrutan dan seleksi. Proses penerimaan pegawai dilaksanakan secara tansparan, obyektif, akuntabel dan bebas KKN melalui penerimaan pegawai berbasis CAT, pengumuman hasil seleksi dan penerimaan pegawai secara luas kepada masyarakat melalui website resmi.

c. Pengembangan kompetensi. Pengembangan pegawai berbasis kompetensi dilakukan dengan menyusun standar kompetensi jabatan, melaksanakan asessment pegawai, melaksanakan identifikasi kebutuhan pengembangan kompetensi, menyusun rencana pengembangan kompetensi pegawai, melaksanakan pengembangan kompetensi pegawai, dan monitoring serta evaluasi pengembangan pegawai berbasis kompetensi secara berkala.

d. Penilaian kinerja dan penghargaan. Penilaian kinerja dilakukan melalui penetapan kinerja individu melalui penyusunan indikator kinerja individu, penerapan penetapan indikator kinerja individu oleh seluruh perangkat daerah, pelaksanaan pengukuran kinerja individu secara bulanan/triwulanan oleh seluruh perangkat daerah, penyusunan laporan pencapaian kinerja individu oleh masing-masing pegawai, serta pelaksanaan monitoring dan evaluasi atas pencapaian kinerja individu. Di samping itu, pemerintah Kabupaten Sanggau juga menyusun pedoman 
akuntabilitas kinerja, mengembangkan penyusunan indikator kinerja individu berbasis elektronik di mana semua perangkat daerah menginput indikator kinerja individu dalam aplikasi, membangun dan mengembangkan perjanjian kinerja/ pengukuran kinerja berbasis elektronik, dan pengembangan aplikasi pohon kinerja berbasis elektronik. Pemberian sanksi dan reward diberikan atas pelaksanaan aturan disiplin/kode etik/ kode perilaku pegawai

e. Promosi, rotasi dan karir. Promosi jabatan dilakukan secara terbuka melalui penyusunan kebijakan promosi jabatan secara terbuka, penyusunan rencana penerapan kebijakan promosi jabatan, pelaksanaan promosi jabatan secara terbuka untuk pimpinan tinggi, dan pengumuman setiap tahapan seleksi secara terbuka melalui website.

\section{Pemerintah Kabupaten Pati}

Arah kebijakan yang dilakukan Pemerintah Kabupaten Pati terkait Smart ASN terdapat pada Peraturan Bupati Pati Nomor 86 Tahun 2020 tentang Road Map Reformasi Birokrasi Pemerintah Kabupaten Pati Tahun 2021-2025.

a. Perencanaan. Arah kebijakan terkait perencanaan adalah penyusunan dokumen perencanaan kebutuhan pegawai sesuai kebutuhan organisasi, penyusunan analisis jabatan dan analisis beban kerja, dan evaluasi jabatan. Perencanaan kebutuhan/formasi jabatan didasarkan atas kebutuhan organisasi sesuai dengan peta jabatan yang telah ditetapkan oleh PPPK.

b. Perekrutan dan seleksi. Proses perekrutan dan seleksi dilakukan melalui penerimaan pegawai secara transparan, obyektif, akuntabel dan bebas KKN. Upaya yang dilakukan dalam mendapatkan ASN yang baik dimulai dari perbaikan sistem rekrutmen ASN secara kompetitif berbasis kompetensi dengan menggunakan Computer Assisted Test (CAT). Bagi peserta seleksi CPNS yang memenuhi nilai ambang batas kelulusan/passing grade akan diambil kelipatan tiga besar berdasarkan alokasi kebutuhan/formasi masing-masing jabatan.

c. Pengembangan kompetensi. Pengembangan kompetensi dilakukan dengan menempatkan pegawai telah sesuai dengan standar kompetensinya, dan mengembangkan kompetensi pegawai sesuai kebutuhan unit kerja melalui proses pendidikan dan pelatihan. 
d. Penilaian kinerja dan penghargaan. Pada penilaian kinerja Pemerintah Kabupaten Pati melakukan penyusunan regulasi penetapan kinerja individu, penyusunan perencanaan kinerja tahunan, pembuatan aplikasi akuntabilitas kinerja dalam bentuk pembuatan aplikasi SAKIP yang terintegrasi dengan sistem perencanaan penganggaran dan pelaporan. Selama ini ukuran kinerja individu belum sepenuhnya mengacu kepada kinerja organisasi dan menjadi dasar pemberian reward dan punishment.

e. Promosi, rotasi dan karir. Pemerintah Kabupaten Pati melakukan penyusunan regulasi pedoman promosi jabatan dimana promosi jabatan dilakukan secara terbuka. Upaya lain yang dilakukan dalam mendorong terciptanya ASN unggul dan berdaya saing adalah diterapkannya Talent Pool ASN sebagai dasar pengembangan karir ASN yang btransparan, kompetitif dan berbasis merit.

\section{Pemerintah Kabupaten Gowa}

Arah kebijakan yang dilakukan Pemerintah Kabupaten Gowa terkait Smart ASN terdapat pada Peraturan Bupati Gowa Nomor 34 Tahun 2020 tentang Road Map Reformasi Birokrasi Pemerintah Daerah Tahun 2020-2024.

a. Perencanaan. Di tahap perencanaan, Pemerintah Kabupaten Pangkep akan menerbitkan dokumen rencana redistribusi pegawai, proyeksi kebutuhan pegawai lima tahun ke depan, melakukan perhitungan formasi jabatan, melakukan analisis jabatan dan evaluasi jabatan, membuka formasi jabatan, dan melaksanakan mutasi pegawai dengan mempertimbangkan hasil asessment.

b. Perekrutan dan seleksi. Proses perekrutan pegawai dilakukan secara transparan, objektif, akuntabel, dan bebas KKN yang dimulai dari pengumuman, pendaftaran, persyaratan, proses seleksi, dan pengumuman hasil.

c. Pengembangan kompetensi. Pengembangan kompetensi dan karir ASN didasarkan pada hasil/monitoring dan evaluasi kinerja dan kebutuhan organisasi. Pengembangan kompetensi dan karir ASN dilakukan dengan cara menyusun standar kompetensi jabatan, menerbitkan dokumen rencana pengembangan kompetensi yang didasarkan pada hasil identifikasi kebutuhan pengembangan.

d. Penilaian kinerja dan penghargaan. Penilaian kinerja dilakukan melalui penetapan dan penerapan ukuran kinerja individu disertai dengan pengukuran kinerja secara berkala melalui monitoring dan evaluasi. Penetapan kinerja dilakukan melalui 
penandatanganan pakta integritas seluruh pegawai. Hasil penilaian kinerja individu kemudian akan ditindaklanjuti dalam bentuk penguatan implementasi reward and punishment berdasarkan kinerja. Penilaian kinerja diintegrasikan dalam sebuah sistem informasi kinerja.

e. Promosi, rotasi dan karir. Promosi untuk pengisian jabatan struktural dilakukan melalui promosi terbuka pengisian jabatan pimpinan tinggi secara kompetitif dan obyektif, dan melaksanakan rotasi dan pengembangan karir pegawai melalui pertimbangan hasil assessment. Guna menunjang pelaksanaan promosi dan rotasi, Pemerintah Kabupaten Gowa melaksanakan pemetaan dan penerapan manajemen talenta, serta penguatan database dan sistem informasi kepegawaian untuk pengembangan karir dan talenta ASN.

f. Peningkatan kesejahteraan. Di samping pemberian gaji, peningkatan kesejahteraan salah satunya dilakukan melalui pemberian tunjangan kinerja berdasarkan capaian kinerja individu.

\section{Pemerintah Kabupaten Pangkep}

Arah kebijakan yang dilakukan Pemerintah Kabupaten Pangkep terkait Smart ASN dapat dilihat pada road map Reformasi Birokrasi 2020-2024.

a. Perencanaan. Di tahap perencanaan, Pemerintah Kabupaten Pangkep sebelum membuka formasi penerimaan atau pun distribusi pegawai, terlebih dahulu melakukan perhitungan proyeksi kebutuhan pegawai lima tahun ke depan, menyusun formasi jabatan, melakukan analisis jabatan dan evaluasi jabatan, membuka formasi jabatan, dan melaksanakan mutasi pegawai dengan mempertimbangkan hasil asessment.

b. Perekrutan dan seleksi. Perekrutan dan seleksi pegawai dilakukan setelah melakukan proses perencanaan, menyusun persyaratan perekrutan pegawai dengan jelas dan tidak diskriminatif dengan menggunakan sistem Computer Assisted Test (CAT), menginformasikan penerimaan pegawai secara luas kepada masyarakat, dan mengumumkan hasil seleksi penerimaan pegawai secara terbuka

c. Pengembangan kompetensi. Pengembangan kompetensi dan karir ASN dilakukan dengan cara menyusun standar kompetensi jabatan, melaksanakan asessment pegawai, melaksanakan pengembangan kompetensi (disesuaikan dengan rencana dan kebutuhan pengembangan kompetensi, hasil asessment, serta hasil penilaian 
kinerja individu), dan melakukan monev pengembangan pegawai berbasis kompetensi secara berkala. Di samping itu Pemerintah Kabupaten Pangkep juga melakukan pengembangan implementasi manajemen talenta dengan melaksanakan workshop, pemetaan manajemen talenta, dan menerapkan manajemen talenta dalam pengisian jabatan pimpinan tinggi. Pengembangan kompetensi diselenggarakan melalui kurikulum konvensional seperti diklat struktural, diklat fungsional, dan diklat/bimtek teknis baik yang bersifat klasikal (tatap muka langsung) maupun nonklasikal (daring).

d. Penilaian kinerja dan penghargaan. Penilaian kinerja dilakukan melalui penetapan dan penerapan ukuran kinerja individu disertai dengan pengukuran kinerja secara berkala melalui monitoring dan evaluasi. Sebelum penilaian kinerja dilakukan, dilaksanakan penandatanganan perjanjian kinerja oleh seluruh pegawai pada tahun berjalan. Hasil penilaian kinerja individu kemudian akan ditindaklanjuti dalam bentuk pemberian penghargaan dan sanksi.

e. Promosi, rotasi dan karir. Promosi untuk pengisian jabatan struktural dilakukan melalui promosi terbuka pengisian jabatan pimpinan tinggi secara kompetitif dan obyektif, membentuk panitia seleksi pengisian jabatan, mengumumkan hasil promosi pengisian jabatan secara terbuka, dan melaksanakan promosi pengisian jabatan berdasarkan hasil seleksi.

f. Peningkatan kesejahteraan. Di samping pemberian gaji, peningkatan kesejahteraan salah satunya dilakukan melalui pemberian tunjangan kinerja berdasarkan capaian kinerja individu.

\section{Pemerintah Kabupaten Blitar}

Arah kebijakan yang dilakukan Pemerintah Kabupaten Blitar terkait Smart ASN terdapat pada Peraturan Bupati Blitar Nomor 76 Tahun 2020 tentang Road Map Reformasi Birokrasi Pemerintah Daerah Kabupaten Blitar Tahun 2020-2024.

a. Perencanaan. Perencanaan dilakukan melalui perhitungan kebutuhan pegawai (anjab dan ABK) sesuai kebutuhan organisasi, formasi jabatan diusulkan sesuai dengan kinerja utama perangkat daerah, penyusunan formasi kebutuhan pegawai dan evaluasi jabatan dengan melibatkan seluruh perangkat daerah, penyusunan dan penetapan standar kompetensi jabatan dan informasi faktor jabatan, penetapan formal kebijakan dan dokumen redistribusi pegawai 
b. Perekrutan dan seleksi. Sistem penerimaan pegawai dilakukan secara online, transparan, dan akuntabel, obyektif dan bebas KKN

c. Pengembangan kompetensi. Pemerintah Kabupaten Blitar melaksanakan sertifikasi kompetensi ASN dan kurikulum diklat pimpinan perangkat daerah yang berorientasi inovatif dan budaya kinerja, penguatan kompetensi dan kecukupan SDM aparatur perangkat daerah yang dapat mendukung target kinerja, penyusunan dokumen kebijkaan rencana dan jenis diklat kompetensi ASN, penerapan kebijakan pengembangan kompetensi pegawai ASNsesuai kebutuhan organisasi, introduksi pendekatan diklat berbasis studi kasus dan proyek inovasi perubahan, pengembangan kerjasama instansi lain dalam pelaksanaan diklat, penguatan tugas dan fungsi tim pelaksana diklat dalam mengembangkan pendekatan dan materi kurikulum.

d. Penilaian kinerja dan penghargaan. Penilaian kinerja dilakukan melalui pelembagaan pakta integritas dan perjanjian kinerja ke setiap jabatan, indikator kinerja sudah disusun berjenjang (cascading) dan kesesuaian antara individu ke kinerja perangkat organisasi, review cascading dan crosscutting kinerja antar perangkat daerah dalam mendukung target kinerja RPJMD, evaluasi capaian kinerja secara triwulanan. Kebijakan reward dan punishment pegawai di seluruh perangkat daerah dikaitkan dengan kinerja tambahan penghasilan.

e. Promosi, rotasi dan karir. Pemerintah Kabupaten Blitar melaksanakan kebijakan sistem promosi jabatan dengan melibatkan tim independen dan stakeholder lengkap. Hasil seleksi diumumkan secara terbuka dan realtime. Dilakukan pula perekapan data base hasil asessment untuk seluruh pegawai, pembentukan dan penerapan talent pool bagi pegawai yang memiliki kepemimpinan dan kompetensi birokrasi. Selain itu dilaksanakan pula penguatan kebijakan integrasi kinerja dan karir pegawai.

f. Peningkatan kesejahteraan. Penerapan hasil capaian kinerja dijadikan dasar dalam pemberian tunjangan kinerja.

\section{Birokrasi 4.0}

Pencapaian revolusi industri 4.0 membutuhkan birokrasi 4.0 yang meliputi percepatan pelayanan, efisiensi pelayanan, akurasi pelayanan, dan fleksibilitas kerja, di mana segala urusan dilaksanakan menggunakan jaringan internet (internet of things). Hal ini juga terlihat di pemerintah daerah yang menjadi objek penelitian yang menggunakan jaringan internet 
dalam mempermudah pekerjaan. Penguasaan pegawai terhadap internet akan memudahkan organisasi dalam proses transformasinya di bidang pengelolaan ASN. Hal ini juga sekaligus menjawab hasil survey Deloitte di 70 negara yang melibatkan 1.200 pegawai pemerintah yang menunjukkan bahwa teknologi digital telah berdampak sangat signifikan pada perubahan cara dan pola kerja pemerintah. Perkembangan teknologi informasi dan komunikasi menyebabkan perubahan tatanan kehidupan hampir di segala bidang, yang mempengaruhi lingkungan kerja ASN. Penguasaan teknologi informasi memberikan peluang optimasi dalam pelaksanaan tugas dan fungsi, yang diharapkan dapat meningkatkan kinerja individu maupun organisasi.

Berdasarkan Grand Design Pembangunan ASN 2020-2024, penerapan teknologi informasi di birokrasi akan menggiring pada struktur organisasi K/L/P yang lebih ramping. Tumpang tindih kewenangan akan terkoreksi dengan sendirinya sehubungan dengan penerapan sistem berbasis TIK. Di samping itu, tata kerja birokrasi yang selama ini berjenjang, akan menjadi lebih sederhana. Dikombinasikan dengan generasi ASN yang pada tahun 2020-2024 akan mendominasi birokrasi, maka tata kerja yang lebih sederhana dan dengan dukungan TIK memungkinkan untuk dilakukannya perampingan organisasi/ kelembagaan.

Dalam hal perencanaan, perencanaan kebutuhan ASN dalam penelitian ini dari tahun 2019 hingga 2024 telah mempertimbangkan beban kerja organisasi sesuai dengan mandatnya dalam melaksanakan pembangunan daerah. Beban kerja organisasi dituangkan dalam dokumen Analisis Beban Kerja yang kemudian dijadikan dasar dalam merencanakan kebutuhan ASN selama lima tahun ke depan. Di samping itu, dibutuhkan pula keahliankeahlian tertentu yang diperlukan sesuai prioritas pengembangan daerah. Keahlian-keahlian ini harus tergambar dalam peta jabatan. Hal ini telah pula dilakukan oleh keenam daerah penelitian dimana keenam daerah tersebut telah memasukkan dalam road map penyusunan analisis jabatan yang dilengkapi dengan peta jabatan sehingga informasi jabatan dapat tergambarkan dan menjadi dasar dalam penyusunan analisis beban kerja. Hanya saja belum terdapat informasi mengenai jabatan-jabatan yang dapat diisi oleh PPPK dalam peta jabatan yang dibuat atau informasi terkait jabatan-jabatan yang langka danprofesional yang dapat diisi oleh PPPK. Hal ini didasarkan pada PP Nomor 49 Tahun 2018 tentang Manajemen Pegawai Pemerintah dengan Perjanjian Kerja (PPPK) yang menyebutkan bahwa formasi 
PPPK disiapkan untuk jabatan-jabatan yang langka dan profesional yang akan memperkuat ASN.

Terkait pengadaan ASN, Grand Design Pembangunan ASN 2020-2024 menyebutkan bahwa proses pengadaan ASN harus lentur, agar tidak terjebak merekrut ASN yang ternyata tidak capable, atau tidak memiliki kompetensi yang memadai. Dalam dokumen Road Map Reformasi Birokrasi, seluruh pemerintah daerah yang menjadi objek penelitian masih melaksanakan proses perekrutan yang bersifat nasional, yaitu proses penerimaan pegawai dilaksanakan secara tansparan, obyektif, akuntabel dan bebas KKN melalui penerimaan pegawai berbasis CAT. Upaya yang dilakukan ini merupakan salah satu cakupan dalam sistem merit. Cakupan lainnya adalah memberikan remunerasi yang setara untuk pekerjaanpekerjaan yang setara dan menghargai kinerja yang tinggi. Tujuannya mempertahankan ASN melalui pemberian kompensasi yang adil dan layak. Dalam objek penelitian ini, arah kebijakan pemerintah daerah dalam hal pemberian tunjangan kinerja dilakukan berdasarkan penerapan hasil capaian kinerja, meski belum sepenuhnya perhitungan tunjangan kinerja didasarkan pada kinerja.

Dalam hal pengembangan kompetensi, dari enam daerah penelitian terdapat tiga daerah yang melaksanakan asessment untuk mengetahui kompetensi dan kinerja seluruh pegawai yang bersangkutan. Padahal hal ini penting mengingat Grand Design Pembangunan ASN 2020-2024 telah menekankan perlunya pemetaan kompetensi dan kinerja seluruh pegawai, bukan hanya pejabat struktural pimpinan tinggi. Dalam Grand Design Pembangunan ASN 2020-2024 terdapat 4 (empat) kelompok besar, yaitu: (a) Pegawai dengan kualifikasi dan kompetensi memadai, dan berkinerja baik, dipertahankan untuk dikembangkan lebih lanjut; (b) Pegawai dengan kualifikasi dan kompetensi yang tidak sesuai/memadai, namun berkinerja baik, diberikan kesempatan untuk mengikuti program peningkatan kualifikasi dan pengembangan kompetensi; (c) Pegawai dengan kualifikasi dan kompetensi yang sesuai/memadai, namun tidak/kurang berkinerja, dipertimbangkan untuk dipindahkan ke unit kerja/instansi lain (mutasi/ rotasi) yang memungkinkan yang bersangkutan mengembangkan karier. (d). Pegawai dengan kualifikasi dan kompetensi yang tidak sesuai/memadai; dan tidak berkinerja, difasilitasi untuk bertransformasi menjadi entrepreneur. Transformasi diterapkan dengan memberikan kompensasi yang memadai agar yang bersangkutan dapat memulai/ merintis usaha (golden handshake). 
Terkait penyusunan standar kompetensi jabatan, hampir seluruh daerah dalam penelitian ini telah memasukkan penyusunan standar kompetensi jabatan dalam road map reformasi birokrasi. Hal ini merupakan kewajiban setiap K/L/D dan merupakan bagian dari transformasi penyelenggaraan pengembangan kompetensi. Grand Design Pembangunan ASN 2020-2024 telah menyebutkan bahwa standar kompetensi jabatan, baik teknis, manajerial, maupun sosial-kultural, hendaknya mempertimbangkan aspek-aspek tantangan dan peluang yang terkait dengan perkembangan era Industri 4.0.

Terkait penilaian kinerja dan penghargaan, Grand Design Pembangunan ASN 2020$\underline{2024}$ telah menyebutkan bahwa perlu ada perubahan paradigma, dari sekedar menilai kinerja menjadi mengelola kinerja. Pada hakekatnya, pengelolaan kinerja (manajemen kinerja), adalah sebuah proses yang terdiri atas 4 (empat) tahap, yaitu: (i) Perencanaan Kinerja; (ii) Pengelolaan Kinerja; (iii) Penilaian Kinerja; dan (iv) Penghargaan dan Sanksi (Reward and Punishment). Hanya dengan penerapan manajemen kinerja secara penuh, akan dapat dibangun spirit kerja dan penciptaan lingkungan kerja yang berkinerja tinggi (high performing organization). Terkait perencanaan kinerja hampir seluruh daerah dalam penelitian ini telah memasukkan perencanaan kinerja individu dalam road map reformasi birokrasi. Upaya-upaya yang dilakukan meliputi: (1) penyusunan indikator kinerja individu, (2) penetapan kinerja individu melalui penyusunan perjanjian kinerja hingga level pelaksana, (3) penyusunan regulasi pedoman penilaian kinerja individu, (4) cascading kinerja hingga level pelaksana. Demikian juga dengan pengelolaan kinerja, di mana upaya-upaya yang dilakukan meliputi: (1) penerapan penetapan indikator kinerja individu oleh seluruh perangkat daerah, (2) pelaksanaan pengukuran kinerja individu secara bulanan/triwulanan oleh seluruh perangkat daerah, dan (3) penginputan indikator kinerja individu dalam aplikasi. Sementara pada penilaian kinerja, upaya yang dilakukan meliputi: (1) penyusunan laporan pencapaian kinerja individu oleh masing-masing pegawai, serta (2) pelaksanaan monitoring dan evaluasi atas pencapaian kinerja individu.

\section{PENUTUP}

Arah kebijakan yang dilakukan pemerintah kab/kota di Indonesia dalam upaya membangun SDM aparatur yang berkualitas dalam rangka mewujudkan Smart ASN pada dasarnya telah mengarah pada Grand Design Pembangunan ASN 2020-2024 yang diterbitkan oleh Kemenpan RB. Terdapat strategi 6P untuk merealisasikan Smart ASN, 
yakni 1) perencanaan, 2) perekrutan dan seleksi, 3) pengembangan kompetensi, 4) penilaian kinerja dan penghargaan, 5) promosi, rotasi dan karir, dan 6) peningkatan kesejahteraan. Keenam pemerintah daerah dalam penelitian ini telah bergerak ke arah strategi di atas meski masih banyak hal yang perlu disesuaikan dan disempurnakan dalam penerapannya.

\section{DAFTAR PUSTAKA}

Adiperdana, Ardan. 20155. Implementasi Reformasi Birokrasi melalui Revolusi Mental Birokrasi sebagai Upaya Membentuk Pemerintahan Kelas Dunia. Jurnal Pendayagunaan Aparatur Negara. Edisi V. Hal.18-35

BPSDM Jawa Timur. 12 Juli 2021. "Obras" ala BPSDM Jatim Bentuk ASN Smart Berkomunikasi. (Online), (https://bpsdm.jatimprov.go.id/news/195/obras-ala-bpsdmjatim-bentuk-asn-smart-berkomunikasi, diakses tanggal 11 Agustus 2021)

Faedlulloh, Dodi, Syamsul Maarif, Intan Fitri Meutia, dan Devi Yulianti. 2020. Birokrasi dan Revolusi Industri 4.0 : Mencegah Smart ASN menjadi Mitos dalam Agenda Reformasi Birokrasi Indonesia. Jurnal Borneo Administrasi. Volume 16 (3). Hal. 313 $\underline{336} \underline{(2)} \underline{(3)} \underline{(4)} \underline{(5)} \underline{(6)}$

Kementerian Pendayagunaan Aparatur Negara dan Reformasi Birokrasi. Grand Design

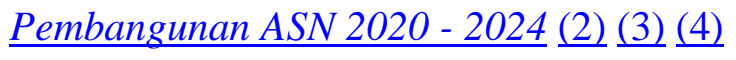

Oktari, Rosi. 2020. Siapkah Kamu jadi Generasi Emas 2045?. (Online), (https://indonesiabaik.id/infografis/siapkah-kamu-jadi-generasi-emas-2045, Diakses tanggal 3 Maret 2021)

Peraturan Bupati Blitar Nomor 76 Tahun 2020 tentang Road Map Reformasi Birokrasi Pemerintah Daerah Kabupaten Blitar Tahun 2020-2024

Peraturan Bupati Gowa Nomor 34 Tahun 2020 tentang Road Map Reformasi Birokrasi Pemerintah Daerah Tahun 2020-2024

Peraturan Bupati Pati Nomor 86 Tahun 2020 tentang Road Map Reformasi Birokrasi Pemerintah Kabupaten Pati Tahun 2021-2025

Peraturan Bupati Sanggau Nomor 4 Tahun 2020 tentang Road Map Reformasi Birokrasi Pemerintah Kabupaten Sanggau Tahun 2020-2024

Peraturan Bupati Tapin Nomor 9 Tahun 2020 tentang Road Map Reformasi Birokrasi Pemerintah Tapin Tahun 2019-2023

Rezky, Monovatra Predy, Joko Sutarto, Titi Prihatin, dkk. 2019. Generasi Milenial yang Siap Menghadapi Era Revolusi Digital (Society 5.0 dan Revolusi Industri 4.0)di 
Bidang Pendidikan melalui Pengembangan Sumber Daya Manusia. Prosiding Seminar Nasional Pascasarjana UNNES. (2) (3) (4)

Saputra, Dwi Prasetya, Febri Kurniawansyah. 2020. Tantangan BKD Kota Malang dalam Menyiapkan ASN di Era Digital. Prosiding Simposium Nasional "Tantangan Penyelenggaraan Pemerintahan di Era Revolusi Industri 4.0"

Tampubolon, Hotner. 2016. Strategi Manajemen Sumber Daya Manusia dan Perannya dalam Pengembangan Keunggulan Bersaing. Cetakan Pertama. Jakarta. Papas Sinar Sinanti. 